\title{
AS IMAGENS URBANAS TECIDAS EM O RETRATO DE DORIAN GRAY, DE OSCAR WILDE
}

\author{
Wanderson Silva Mercês'; Aleilton Santana da Fonseca ${ }^{2}$ \\ 1. Bolsista PROBIC, Graduando em Letras: Português e Espanhol, Universidade Estadual de Feira de Santana, \\ e-mail: wandersonsmerces@gmail.com \\ 2. Orientador, Departamentode Letras e Artes, Universidade Estadual de Feira de Santana, \\ e-mail: aleilton50@gmail.com
}

PALAVRAS-CHAVE: Imagens urbanas; O Retrato de Dorian Gray; Oscar Wilde.

\section{INTRODUÇÃO}

Realizamos através deste projeto de iniciação científica um estudo de natureza biobibliográfico que está fundamentado na biografia do escritor Oscar Wilde e de seu único e polêmico romance, $O$ Retrato de Dorian Gray (objeto principal da análise).

Com base no material de análise, selecionamos vários diálogos que trazem à tona o debate sobre a importância que teve para o autor as representações literárias e poéticas da Era Vitoriana e da Londres industrial, bem como as características da Escola Literária do Realismo.

A proposta considera além da relevância do autor no meio acadêmico, seu conjunto de poemas, contos, ensaios, bem como peças teatrais, que lhes deram grande destaque nas décadas de 80 e 90 do século XIX por representarem sua aguda visão crítica acerca da sociedade Vitoriana. Neste sentindo, abordamos a memória e a obra do autor e destacamos sua importância para o espaço acadêmico da contemporaneidade.

As reflexões que foram construídas no estudo fundamentam-se em bibliografia específica, em especial Monica Charlot e Rolland Marx (1993), organizadores do livro Londres, 1851-1901: a era vitoriana ou o triunfo das desigualdades e Marcello Rollemberg (2001) autor do livro Sempre seu, Oscar., que faz indicações tocantes à vida de Wilde.

\section{MATERIAL E MÉTODOS}

O estudo está fundamentando em bibliografia específica que são: a biografia do autor e sua obra, O Retrato de Dorian Gray; os livros: Londres, 1851-1901: a era vitoriana ou o triunfo das desigualdades, dos organizadores Monica Charlot e Rolland Marx e Sempre seu, Oscar., de Marcello Rollemberg. Além desse aporte teórico, utilizamos textos informativos e teóricos, que nos deram um grande apoio referencial. Através de todos esses materiais foi realizada uma apreciação crítica do romance, tendo 
em vista a contextualização do autor e da obra na sua época e na contemporaneidade. Para tal, utilizamos o método vazado em comentário, interpretação e análise.

\section{DISCUSSÃO}

Oscar Wilde nasceu em 1854, na cidade de Dublin, Irlanda. Estava morando em Londres, Inglaterra, quando publicou seu romance O Retrato de Dorian Gray, estabelecendo-se como figura importante para a cena cultural da cidade e um escritor em ascensão. Casou-se com Constace Lloyd e teve dois filhos: Cyril e Vyvyan. Publicou poemas, ensaios, contos e peças teatrais, como Um marido ideale A importância de ser prudente, entre outras. Foi condenado a dois anos de prisão e trabalhos forçados após o Marquês de Queensberry, pai de Alfred Douglas, tê-lo acusado de homossexualidade (prática considerada crime durante a Era Vitoriana). O encarceramento tomou além da liberdade, seu dinheiro e sua saúde. Quando saiu da prisão, em 1900, morreu de meningite, exilado na França, relegado ao anonimato e respondendo por Sebastian Melmonth.

O tema Representação (R.) tem sido amplamente discutido por vários estudiosos no campo filosófico, sociológico e literário. Ao nos aproximarmos do conceito sobre R. concebido pela Filosofia, compreendemos que ela é o ser que por outro ser está representado. "O uso desse termo foi sugerido aos escolásticos pelo conceito de conhecimento como 'semelhança' do objeto. 'Representar algo' - dizia Tomás de Aquino - significa conter a semelhança da coisa." (ABBAGNANO, 2012, p. 1007). Estreitando um pouco mais a definição de R. e trazendo-a para o campo da Literatura, entendemos que Representação Literária (R.L) assemelha-se a própria R., por ser a R.L o resultado de uma prática bastante comum entre os artistas: perceber, interpretar e narrar o meio que lhe cerca.

Londres é a cidade das contradições. O caos que surgiu com o "progresso" advindo da Revolução Industrial é um ótimo exemplo desse traço londrino. O contraste na cidade pode ser percebido desde a sua localização geográfica, pois é situada às margens do rio Tâmisa e dividida entre "margem esquerda" e "margem direita", bem como em sua superpopulação. Segundo Reclus (1885 apud CHARLOT; MARX 1993, p. 37), a cidade contava com "uma população de 4.211.056 habitantes"

No seu único e polêmico romance, Wilde narrou a percepção e a interpretação que deu à sociedade Vitoriana e ao urbano caótico em que estava inserido; entregou uma obra bela à uma sociedade Realista, avessa à supervalorização do sentimentalismo 
romântico, que não imaginava que obras literárias produzidas naquele momento fossem capazes de narrar sua podridão. Para Wilde (1973, p. 9) "A aversão do século XIX ao Romantismo é a cólera do Calibã por não ver seu próprio rosto no espelho."

Quando o autor de um livro publica uma obra, ele apresenta ao leitor um fato histórico através do imaginário, que parte do real. Oscar Wilde ao publicar em 1890 " $O$ Retrato de Dorian Gray em capítulos na Lippincott's Magazine [e no ano seguinte] em livro, com capítulos adicionais e um novo prefácio.” (ROLLEMBERG, 2001, p 21), não desejava provar ao leitor absolutamente nada a seu respeito, mas sim narrar o que percebeu e interpretou da Era Vitoriana e da Londres industrial.

\section{CONSIDERAÇÕES FINAIS}

Ao relermos criticamente o romance $O$ Retrato de Dorian Gray no contexto da contemporaneidade, constatamos a atualidade da proposta estética e da crítica social do escritor Oscar Wilde. Levando em conta os aspectos do Realismo, pesquisamos na obra ficcional os temas voltados ao social, cultural, bem como ao artístico, afim de identificarmos alguma similaridade entre os valores brasileiro-europeu e assim reiterarmos a permanência do romance no cenário sociocultural contemporâneo; à medida que pesquisávamos, fomos conduzidos a pesquisar, para além do romance, conteúdos relacionados ao histórico, político, econômico e filosófico também.

O personagem principal (Dorian Gray) da obra analisada, homem distinto na sociedade de Londres, explicitamente foi o meio pelo qual o autor espetou as chagas da sociedade Vitoriana, dentre elas, podemos destacar: o culto a beleza, a supervalorização da juventude em detrimento da repugnância ao envelhecimento, os abismos sociais, a imobilidade social, o papel da igreja, bem como o dualismo do ser humano entre bem e o mal, representado, fidedignamente pelo corpo e alma, Dorian Gray pessoa e Dorian Gray retrato.

Tudo aquilo que Oscar Wilde criticou corajosamente no que se tornou seu único romance a respeito do padrão moral imposto pela sociedade Vitoriana merecem críticas na sociedade atual, não apenas a europeia, mas também a brasileira. Tudo que foi pesquisado para a realização do estudo sobre as representações literárias, as imagens urbanas da Inglaterra caótica, o Realismo a todo vapor na Europa revolucionária e, sobretudo, a análise do romance não nos deixou dúvidas de que temas urbanos da sociedade descrita por Wilde em 1890, tais como o patriarcado, machismo, homofobia e a impunidade dos ricos, é tão atual quanto. 


\section{REFERÊNCIAS}

Obra de Oscar Wilde:

WILDE, Oscar. O Retrato de Dorian Gray. Tradução de Oscar Mendes. Rio de Janeiro: Abril, 1973.

\section{Referências gerais:}

ABBAGNANO, Nicola. Dicionário de Filosofia. Tradução da 1. ed. brasileira coordenada e revista por Alfredo Bosi; revisão da tradução e tradução dos novos textos, Ivone Castilho Benedetti. 5. ed. São Paulo: Martins Fontes, 2007.

CHARLOT, Monica; MARX, Roland. (Org.). Londres, 1851-1901: a era vitoriana ou o triunfo das desigualdades. Tradução de Lucy Magalhães. Rio de Janeiro: Jorge Zahar Ed., 1993.

ROLLEMBERG, Marcello. (Org., Trad., Apres.). Sempre seu, Oscar: uma biografia epistolar. São Paulo: Iluminuras, 2001. 